\title{
Essee kirjutamisest kirjanduse eriala kursusel: üliõpilaste arusaamad ja õppejõu tagasiside
}

\author{
Andrus Org ${ }^{\mathrm{a} 1}$ \\ ${ }^{a}$ Tartu Ülikooli kultuuriteaduste instituut
}

\begin{abstract}
Annotatsioon
Essee on oma olemuselt terviklik kirjatöö, arvamuse või suhtumise sügavuti väljendus mingil kindlal teemal. Kõrgkoolipedagoogikas on akadeemilist ehk Inglise stiilis esseed kasutatud enamasti individuaalse hindelise kirjutamisülesandena, mis võimaldab subjektiivseid vaatenurki siduda filosoofiliste või teaduslike seisukohtadega. Siinse artikli eesmärk on käsitleda akadeemilise essee kui arutleva tekstitüübi kirjutamisega seotud metodoloogilisi probleeme kirjutamisõpetuse vaatenurgast. Artikkel tugineb tegevusuuringule, mis hõlmab Tartu Ülikooli kultuuriteaduste instituudi eesti kirjanduse eriala bakalaureuseastme kursuse „Proosateksti analüüs“ viimase nelja aasta arendustööd. Eri aastakäikude kursustelt kogutud andmete kvalitatiivsest analüüsist selgub, et peamised raskused essee kirjutamisel puudutavad mitmesuguseid tekstiloomeoskusi, nt sobiva analüüsitasandi ja -meetodi valimist, tervikteksti ülesehitust, lõigu struktuuri ja sidusust, argumentide sõnastust. Samas aitasid mitmed ainedidaktilised muudatused - individuaalne konsultatsioon, essee etapiviisiline kirjutamine, nii esmakui ka lõppvariandi tagasisidestamine - esseede kvaliteeti ja lõpphinnet oluliselt parandada. Artiklis antakse mitmeid didaktilisi soovitusi ja jagatakse veendumust, et essee kirjutamist on võimalik alati tõhusamalt õpetada.
\end{abstract}

Võtmesõnad: tegevusuuring, akadeemiliste tekstide kirjutamine, kirjutamisõpetus kõrgkoolis, essee kirjutamine, õppejõu tagasiside

\section{Teoreetilised lähtekohad}

Akadeemiliste tekstide kirjutamine kuulub lahutamatult tänapäeva kõrgkooliharidusse. Sultan (2013, lk 139) määratleb akadeemiliste tekstide kirjutamist kui õppe- ja teadusasutustes harrastatavat stiililiselt markeeritud 
kirjutamisviisi, kus objektiivse käsitluslaadi huvides kasutatakse kriitilist analüüsi, põhjendustele ja näidetele tuginevat argumentatsiooni, mis omakorda on loogiliselt struktureeritud. Akadeemiliste tekstide kirjutamine on oluline õppimismoodus, mitte ainult selleks, et teadmisi omandada ja edastada, vaid ka selleks, et soodustada õppija kognitiivset arengut ja kriitilist mõtlemist (Carvalho, 2005). See on kasulik ja tõhus tööriist sisukaks mitmetasandiliseks õppimiseks (Tynjala, Mason, \& Lonka, 2001). Siiski ollakse tänapäeval seda meelt, et akadeemiliste tekstide kirjutamist ei ole ülikoolis mõttekas õppida eraldi kursusena, vaid see tuleb ühitada eriala- ja aineõpingutega (Schillings, Roebertsen, Savelberg, \& Dolmans, 2018). Tekstide kirjutamine on erialaõppes asendamatu õpitegevus (Blau, 2003, lk 151).

Mis tahes akadeemilise teksti kirjutamist tuleb vaadelda kompleksse oskusena: see hõlmab ühtaegu nii keelekasutustavade valdamist, kirjutamisprotsessi kavandamist, kirjutamistehnika tundmist kui ka kirjaliku suhtluse mõistmist. Selle tervikliku protsessi juures on olulisim kirjutaja arusaam teksti eesmärgipüstitusest ja tähendustasanditest. Kõige jõulisemat ja ainulisemat mõju akadeemiliste tekstide kirjutamisele avaldab mõistagi tagasiside kas õppejõult või kaasõppijatelt (Schillings et al., 2018). Tudengi vaatenurgast on omakorda tähtis leida kirjutamiseks sisemine motivatsioon - ükski kohustus ega preemia ei suuda seda asendada (Luks, 2007).

Esseed kui žanri on keeruline defineerida, sest seda kasutatakse katusmõistena eri tüüpi akadeemiliste kirjutiste kohta, mille ülesehitus, väitestik ning keele- ja stiiliregister võivad erialati suurel määral varieeruda (Johns, 2008). Essee žanrikonventsioonid pole meie kultuuriruumis üheselt paigas: üldhariduskoolides vaadeldakse esseed tavapäraselt arutleva kirjandina, kõrgkoolides oodatakse sellelt sageli akadeemilise uurimistöö kvaliteeti. Esseekirjutamist mõistetakse eri teadusdistsipliinides võrdlemisi erinevalt: pole ühesugust, kõiki valdkondi rahuldavat akadeemilist formaati (Samraj, 2004). Erinevused võivad ilmneda kas essee tüübis (nt narratiivne, deskriptiivne, ekspositoorne), kirjutamislaadis (nt kriitiline, komparativistlik, analüütiline, reflektiivne, konstruktiivne, informatiivne, autobiograafiline) või ainevaldkonnas (nt filosoofiline, ajalooline, kultuurilooline, kirjanduslik, poliitiline). Essee ajaloolise järjepidevuse saladus peitub ilmselt žanri paindlikus kõikehõlmavuses, niisiis ka võimes täita eri funktsioone (Andrews, 2003). Kuigi klassikalisel kujul hõlmab essee nii loogikat, dialektikat kui ka retoorikat, annab see tudengile võimaluse avada isiklikke perspektiive, ent samal ajal mängida ka žanritunnustega.

Kõrgkoolipedagoogikas on tavaks teadmisi ja oskusi kontrollida peamiselt kirjalikus vormis, mistõttu mitmesugused kirjalikud tööd (nt esseed, retsensioonid, raportid, projektid, vikiartiklid, uurimused) täidavad olulist rolli 
õpiväljundite hindamisel. Essee on kujunenud kõrgkooliõppes kõige tavapärasemaks žanriks (Paltridge, 2004), mida üliõpilased peavad kirjutama iseäranis humanitaar-, sotsiaal- ja kunstivaldkonnas (Wingate, 2012). Essee, esindades ratsionalistlikku ja humanistlikku paradigmat, ülistab eksplitsiitset ja sugestiivset mõttetegevust, mis mõjub akadeemilisele ringkonnale atraktiivselt (Andrews, 2003). Kuigi essee on kõrgkoolis laialt levinud žanr, pole see ilmselt oma hägusate ja varjatud omaduste tõttu kujunenud teadustekstide hierarhias piisavalt prestiižseks (Wingate, 2012), mistõttu uuemal ajal on selle jätkusuutlikkuses mõnevõrra kaheldud (Andrews, 2003).

Kvaliteetse essee kirjutamine eeldab ühtaegu nii teadmisi kui ka kogemusi (Hounsell, 1997), mida algajatel esseistidel sageli napib. Tudengite kirjutamiskogemuste pagasit mõjutab nende varasem hariduslik taust ja õpikogemus kõrgkoolis (McEwan, 2017), nii näiteks võib kirjutamisoskus suuresti erineda bakalaureuseõppe esmakursuslastel ja magistriastmes õppijatel. Arvestada tuleb ka asjaoluga, et õpperühmas on mõnikord õppekeelt võõrkeelena kõnelevaid või rahvusvahelise õpikogemusega tudengeid, kelle arusaam esseežanrist võib olla erineva kultuuritausta või -kogemuse tõttu hoopis teistsugune (Paltridge, 2004).

Uurimustes on korduvalt täheldatud, et tudengite ettekujutused ja arusaamad esseežanrist lahknevad sageli aine õppejõu ootustest, tema esitatud suunistest ja hindamiskriteeriumitest (Andrews, 2003; Lea \& Street, 1998; McEwan, 2017; Norton, 1990; Wingate, 2012). Seepärast ei tohiks essee kirjutamine olla ühelgi ainekursusel enesestmõistetav, vaid kirjutamisõpetus tuleks lõimida kõigisse distsipliinidesse, kus akadeemiliste tekstide kirjutamist nõutakse (Wingate, Andon, \& Cogo, 2011). Asjakohased juhised ja parimate kirjatööde näited aitavad üliõpilastel kirjutamisülesannetega oluliselt hõlpsamalt toime tulla kui esseekirjutamise arvukad käsiraamatud või pikad üksikasjalikud juhendid (Lea \& Street, 1998). Esmajoones ootavad õppijad iga uue kursuse puhul nõudmistes selgeid kokkuleppeid ning konkreetset juhendamisabi (McEwan, 2017).

Esseežanris kirjutamine eeldab kompleksseid tekstiloomeoskusi (Kathpalia \& Heah, 2008), mis kõige üldisemalt jagunevad nelja pädevuskategooriasse: 1) lingvistiline pädevus tähendab keele valdamist selle mis tahes makro- ja mikrotasandil; 2) kognitiivne pädevus peegeldab kirjutaja oskust kriitiliselt mõelda, oma tegevusi hinnata ja metakognitiivseid strateegiaid kasutada; 3) afektiivne pädevus hõlmab oskust väljendada tekstis enda hoiakuid, suhtumist ja uskumusi, näidata välja isiklikke reaktsioone; 4) sotsiaalne pädevus toob tekstis esile mitmesugused intra- ja interpersonaalsed suhted, sh suhte teksti lugejaga. Laiemalt võib essee kirjutamises näha omamoodi sotsiaalset praktikat, mida mõjutavad mitmesugused institutsionaalsed ja distsiplinaarsed asjaolud ning tingimused (Wingate et al., 2011). 
Lepajõe (2011) järgi võib eristada essee (arutleva kirjandi) tekstuaalseid, retoorilisi ja diskursiivseid omadusi. Tekstuaalsest vaatenurgast on essee struktuurilt sidus ja semantiliselt koherentne tervik. Koherentsust tuleb mõista teksti mõiste- ja tähendusseoste võrgustikuna, mida lugeja tajub temaatiliselt sidusa ja sisult terviklikuna. Sellele lisandub teksti kohesioon, mis hõlmab lingvistilisi vahendeid, s.o grammatilisi ja leksikaalseid elemente, mis loovad lausete ja tekstiosade vahel seoseid (Lepajõe, 2011, lk 43-44). Essee retoorilised omadused seostuvad esmajoones tähendusloomega, argumentide veenva esitamise ja lugeja mõjutamisega. Kuna essee on oma laadilt argumenteeriv tekst, on tugeva ja tiheda väitevõrgustiku ülesehitamine esseekirjutuses peamine ülesanne (Wingate, 2012, lk 145). Essee diskursiivsed omadused viitavad mitmesugustele kontekstidele, hõlmates suhteid teiste tekstide ja varasemate traditsioonidega, kuid need peegeldavad ka kirjutaja identiteeti, tema hoiakuid ja suhtumist kõnealusesse teemasse (Fairclough, 1992, lk 35-36).

Kuna akadeemilise essee kirjutamine on uue põlvkonna kõrgkoolinoortele tõeline katsumus, pidades silmas nii esseežanri omadusi kui ka üldisi tekstiloomeoskusi, siis vajavad nad konstruktiivset kirjutamisabi, nii metoodilist sekkumist kui ka erialast tuge. Metoodiliselt läbimõeldud, asja- ja jõukohane kirjutamisabi peaks tooma tähelepanu fookusesse kogu kirjutamisprotsessi ja kujundama kompleksselt kõiki kirjutamispädevusi.

\section{Tegevusuuring}

Taust

Pedagoogikas tähendab tegevusuuring (ingl action research, ka teacher research) õpetaja professionaalse kogemuse eesmärgistatud, süstemaatilist ja koostööpõhist uurimist (Cochran-Smith \& Lytle, 2009, lk 9), mille siht on praktilises õpetamistöös midagi muuta ning oma kogemust teistega jagada (Norton, 2009, lk 13). Tegevusuuringu tarbeks sõnastatakse huviäratav küsimus või lahendust nõudev probleem, kogutakse ja analüüsitakse andmeid, võrreldakse neid asjakohase erialakirjandusega ning tehakse saadud tulemuste ja uute teadmiste alusel muudatusi oma senises õpetamispraktikas (Dana, 2016, lk 19-20). Tsükliliselt kavandatud tegevusuuring aitab lahti arutada mõnda igapäevatöö probleemipundart ja pidevalt ennast täiendada.

Siinses tegevusuuringus, mis valmis Tartu Ülikooli hea õpetamise grandi toel, keskenduti akadeemilise essee kui arutleva teksti kirjutamisega seotud metodoloogilistele probleemidele kirjutamisõpetuse vaatepunktist. Tegevusuuringu aluseks oli eesti kirjanduse eriala bakalaureuseastme kursuse „Proosateksti analüüs" (FLKU.05.107) nelja viimase aasta (2015-2018) arendustöö, mis muu hulgas hõlmas mitmesuguseid ainedidaktilisi muudatusi õppeprotsessis. 
Kõnealusel kursusel, kus kontakttunde õppijatega on 32, õpitakse ühe semestri vältel tundma tekstianalüüsiks vajalikke mõisteid ja meetodeid, tosinale tekstinäitele tuginedes vaadeldakse romaani- ja novelližanrile omaseid poeetilisi väljendusvahendeid. Kursuse jooksul tegelevad üliõpilased iga nädal koduste lugemisülesannetega, millele seminarides järgnevad eri tüüpi rühmatööd, diskussioonid ja debatid. Veel tuleb igal üliõpilasel seminariarutelu käivitamiseks esitada üks slaiditoega lühiettekanne (u 10 minutit), milles vaadeldakse mõnda ühiselt loetud proosateksti kitsamat poeetikaaspekti. Kursuse rõhuasetus on suulisel tekstianalüüsil, millele pakuvad vaheldust väiksemad kirjutamisülesanded.

Kursus lõpeb eristavalt hinnatava esseega, milles komparativistlikule ehk võrdlevale kirjutamisstrateegiale tuginedes käsitletakse kahte vabalt valitud proosateost, kas romaani, novelli või muus proosažanris teksti ligikaudu 2000sõnalises mahus (6-7 lk), valides vaatenurgaks pasliku teema-, narratiivivõi poeetikatasandi. Kuigi kursuse fookus pole esseekirjutamise spetsiifikal, tuleb õnnestunud essees tagasiside toel lahata ilukirjandusteoste poeetikat, avada dialoogilisel viisil nende kirjandusloolisi taustu ning moraalseid ja esteetilisi väärtusi. Analüüsioskusi edendav diskussioon ja sellele järgnevad refleksiooniülesanded moodustavad siin esseekirjutamise metoodilise tuuma.

\section{Eesmärk ja uurimisküsimused}

Põhiprobleem, mis „Proosateksti analüüsi“ kursusel lahendust vajas, oli seotud akadeemilise essee kvaliteediga. Õppejõu kirjalik tagasiside kursuse lõpuesseedele tõendas, et üliõpilased kogesid essee kirjutamisel nii ainealaseid kui ka metodoloogilisi raskusi, mistõttu esseede keskmine hinne jäi kahetsusväärselt madalaks. Esseekirjutamise metodoloogilised puudused, mis kippusid aastate jooksul korduma ja süvenema, tõstatasid kursuse õppejõu jaoks tõelisi ja kirglikke, praktilisest tööst lähtuvaid küsimusi kirjutamisõpetuse kohta, millele tegevusuuringus püüti vastuseid leida.

1. Mis on essee kirjutamisel peamised metodoloogilised probleemid?

2. Millised ainedidaktilised võtted aitavad toetada essee kirjutamist?

3. Mil viisil saaks akadeemilise essee kirjutamise oskusi edasi arendada?

Tegevusuuringu eesmärk oli seega kindlaks teha, mil viisil saab õppejõud esseekirjutamist efektiivsemalt toetada ja kvaliteetsemalt juhendada, et kirjutamisoskusi parandada ning kirjutamisprotsessis ilmsiks tulnud puudused ja eksimused kõrvaldada, et lõpptulemus pakuks rahulolu.

Siinses tegevusuuringus lõimusid nii ainespetsialisti kui ka didaktikaeksperdi vaatenurk: esimesest lähtudes tuli tähelepanu pöörata üliõpilaste aineteadmistele ning oskustele edastada ja rakendada neid teadmisi kirjanduslikul 
alusmaterjalil põhineva essee sisuloomes; teine omakorda tähtsustas viise, kuidas õppejõud saab tõhusamalt kujundada kirjutamisprotsessi, rikastada kirjutamisõpetuse metoodikat, arendada kirjutamist osaoskuste kaupa ning suunata kirjutajat oma arengut hindama. Probleemid, mida õppejõud nende vaatenurkade korral märkas, vajasid konkreetseid praktilisi lahendusi.

Ainedidaktiku vaatenurgast sobib rõhutada, et meisterlikku kirjutamist saab kahtlemata õpetada ja õppida (Luks, 2007): óppejõu ülesanne on kirjutamisprotsessi nii sisuliselt suunata kui ka metoodiliselt toetada. Kirjutajalt eeldab see loomulikku huvi nii kirjutamise kui ka sisu vastu. Siin saavadki haridusliku dialoogi astudes kokku kaks osalist - õppejõud ja üliõpilane -, kelle koostöö tuleks seada akadeemilise essee kirjutamisel eesmärgiks. Terviklikuma pildi saamiseks tuli ka siinses tegevusuuringus esseekirjutamise probleeme vaagida nii õppejõu kui ka üliõpilaste vaatenurgast.

\section{Tegevusuuringu andmestik ja tulemused}

\section{Õppejõu kommentaarid}

Et koguda andmeid, mis aitaksid uurimisküsimustele vastata, analüüsiti esmalt kvalitatiivse sisuanalüüsi meetodil nelja aastakäigu kursuseesseid (elektrooniline andmebaas on artikli autori valduses). Seeläbi püüti kindlaks teha, mis valmistab üliõpilastele akadeemilise essee kirjutamisel raskusi ja millised metodoloogilised eksimused esseid läbivad või neis korduvad. Valimisse kuulusid kõik 78 eri teemal ja tasemel kirjutatud tööd 2. ja 3. aasta humanitaar- ja sotsiaalvaldkonna õppijatelt. Kuna iga üliõpilane sai oma esseele kursuse lõpus kirjalikku tagasisidet, siis lähtuti andmekorjes juba varem sõnastatud täheldustest ja märkustest. Aine õppejõu kommentaaridele tuginedes oli võimalik välja sõeluda esmajoones need sisukomponendid, mis peegeldasid esseekirjutamise tüüpilisimaid kitsaskohti.

Nagu esseede horisontaalanalüüsiga tuvastati, on peamised kirjutamisraskused seotud mitmesuguste tekstiloomeoskustega, millele õppejõud on oma kommentaarides osutanud. Alljärgnevalt on õppejõu kommentaarid jagatud induktiivselt viide rühma ${ }^{2}$, arvestades kirjutamisel ilmnenud probleemide mustrilist kordumist essee tekstuaalsete, retooriliste ja diskursiivsete omaduste tasandil. Iga rühma näiteks on toodud väike valik kommentaare, mis kvalitatiivsel viisil osutavad mitmesugustele puudujäkidele.

Norton ja Norton (2001) esitavad näiteks kaheksa kriteeriumit, mille järgi saab esseele tagasisidet anda ja ka seda analüüsida: keskne küsimus, selge ülesehitus, relevantsed argumendid, probleemi mõistmise sügavus, veenev tõendusmaterjal, vajalikud viited, õigekeelsus ja akadeemiline stiil. 
- Sobiva analüüsitasandi ja -meetodi valimine (kirjandusteaduslik vaatenurk)

- Kahe proosateksti sisuline võrdlus ei tööta, olete kumbagi teost vaadelnud justkui omaette ja eraldi, puudub sünteesiv lähenemine.

- Tekstianalüüsi asemel tegelete teose episoodide ümberjutustamisega või piirdute teostes esitatud kirjeldustega.

- Kirjandusteaduslikku veenvust ja täpsust on vähevõitu, väljendate subjektiivseid seisukohti ilma neid põhjendamata või teostest näiteid toomata.

- Teksti terviklik ülesehitus, lõigu struktuur ja sidusus

- Analüüi eesmärk on sissejuhatuses sõnastamata, essee juhtküsimus ei selgu, põhiprobleem on lahti seletamata.

- Esseed tuleks selgemalt ja loogilisemalt struktureerida, alaosadeks jagada, sobivateks lõikudeks liigendada ja mõtted järjestada.

- Lõppsõnas esitatud üldistused ja järeldused ei kasva sujuvalt välja eelnevatest arutluskäikudest, kokkuvõtvad mõtted mõjuvad lihtsakoeliselt ega jää essee lõppakordina kõlama.

- Teemaarendus, argumentide leidmine, mõtteseoste loomine

- Tooniandvad on hajusad mõttepudemed ja hüplikud ideetoorikud, mis ei moodusta sidusat arutlust. Peaksite oma ideid paremini korrastama.

- Puudutate ühte ja sama probleemi mitmes essee alaosas ja eri lõikudes, puudub loogiliselt struktureeritud teemaarendus.

- Kohati on ühes lõigus koos üsna erinevad, omavahel kokkusobimatud või vastukäivad mõttekillud, põhjuse ja tagajärje suhe on mõnel juhul paigast ära.

- Alustekstide refereerimine ja tsiteerimine, nende sidumine oma mõtetega

- Teostest valitud tsitaadid või muu informatsioon pole mõnel juhul asjakohane, vaid mõjub kõrvalise irdosana.

- Võorast mõtet refereerides jääb kohati selgusetuks, milline on Teie enda arvamus või seisukoht neis küsimustes. Võiksite oma isiklikku arvamust julgemalt esitada ja rõhutada.

- Sekundaarallikatest laenatud mõtetesse tuleks mõnel juhul suhtuda kriitilisemalt, samuti pole kõik netiallikad kaugeltki autoriteetsed.

- Mõtete selge ja arusaadav sõnastamine, keeleline korrektsus

- Lausestus on kohati kohmakas ja konarlik, sõnastus vajab viimistlemist ja lihvimist.

- Töös esineb rohkesti mõttekordusi, isegi samas sõnastuses lauseosasid. 
- Olulisi väiteid ja märksõnu võiks rohkem rõhutada, ka tekstitehniliste võtetega esile tõsta.

- Stiil võiks olla akadeemilisem, kaldute kohati liigagi subjektiivsesse väljenduslaadi.

Nagu kommentaaridest ilmneb, on üliõpilaste tekstiloomeoskustele omased mitmesugused tüüpvead, mis kokkuvõtvalt peegeldavad kõiki neid raskusi, millega akadeemilise essee kirjutaja tavapäraselt kokku puutub. Ainedidaktikule on see väärtuslik infokogum, mis aitab peamistele puudustele juba kirjutamisprotsessi alguses ennetavalt tähelepanu pöörata. Samas näib, et ainealase essee kirjutamisse on vaikimisi kaasatud aine õppejõu ootus, millele tekst peab vastama.

Samamoodi nagu Wingate'i uurimuses (2012), võib siingi nentida, et peamised probleemid, mida üliõpilased akadeemilise essee kirjutamisel kogevad, on seotud selge ja veenva argumentatsiooni ülesehitamise, kriitilise vaatenurga leidmise ja iseenda seisukohtade väljendamisega. Samuti võib õppejõu kommentaaridest välja lugeda, et vähese kogemusega kirjutajate põhimure on hõredad ja pealiskaudsed väited, kulunud ja lihtsustavad seisukohad, hüplikud ja katkendlikud mõttepudemed, mis kalduvad mõnel juhul kirjeldamisse või ümberjutustamisse. Kommentaarid osutavad korduvalt sellele, et argumente tuleks veenvamalt ja loogilisemalt põhjendada, neid ka paslike näidete ja tsitaatidega varustada. Õppejõu arusaama kohaselt peab akadeemilise essee kirjutamine andma üliõpilastele võimaluse kriitiliselt mõelda, vastata avatud küsimustele ja lahendada probleeme.

Kommentaarides on osutatud muudelegi probleemidele: kirjutaja enda mõtete vähesus või piiratus tekitab mõttekordusi, arutluse ühekülgsust ja paigalseisu ning tingib irdosade tulva (nt tarbetu ülevaade autori elu- ja loominguloost, üleliigsed tsitaadid, sündmustikku ümber jutustavad osad, teemaga nõrgalt seotud heietused, internetist kopeeritud tekstilõigud). Harv pole ka mulje, nagu esitatud kirjatöö oleks kellegi mõttetegevuse ülessoojendatud versioon, seega napib isiku- ja algupära. Õppejõu märkustes on tähelepanu juhitud ka essee retoorilise funktsiooni nõrkusele, kuna kirjutaja ei suuda arutlemise võtteid (analüüsimist, defineerimist, rühmitamist, näitlikustamist, võrdlemist jm) veenvalt rakendada. Arutluskäikude mõistmist häirib ka see, kui kirjutaja enda mõtteid on keeruline eristada alustekstidest pärit seisukohtadest. Lisaks tuleb tõdeda, et argumendikeskne esseekirjutamine on üliõpilastele paiguti raske ja võõras, mistõttu nõrgalt argumenteeritud ja puudulikult näitlikustatud arutlused, millel puudub kirjutaja isiklik vaatenurk, pälvivad üldjuhul halvema hinde. 
Õppejõu repliigid osutavad üliõpilaste suutmatusele luua esseele loogiline struktuur. See pole mõistagi formaalne nõue, vältimaks hüplikku või hajusat ülesehitust, vaid süvatasandil on teksti ülesehitus lõimitud teema üksikasjaliku valdamise ja koherentse sisu loomisega. Nõrgemates kirjatöödes kohtabki lõikudeks liigendamata või alaosadeks jagamata tekstiplokke, mis parema loetavuse huvides vajaksid vahepealkirju. Samuti ei tähtsusta tudengid essee kirjutamisel lõppsõna rolli, mis üldistaval ja järeldaval viisil peab rõhutama kirjutaja enda positsiooni. Kokkuvõttev tekstiosa mõnel juhul suisa puudub või vajab tõhusat täiendamist, järeldused on pealiskaudsed ega tulene varasemast teemakäsitlusest.

Kinnitust leiab Wingate’i (2012) tähelepanek, et mõned üliõpilased loevad alustekste kriitikameeleta ja kasutavad infot selektiivselt, märkamata detaile ning mõistmata loetud tekstide diskursiivseid eesmärke ja tekstuaalseid kontekste. Üksikasjalikust selgitustööst hoolimata laekub esseid, milles pole suudetud võrdlevat tekstianalüüsi viljakalt rakendada: teisisõnu, kahe proosateose kokkupuutepunktide ja ühisosade sünteesiva paralleelkäsitluse asemel vaadeldakse kumbagi teksti omaette, sunnitud võrdlus tekitatakse paremal juhul vaid kokkuvõtlikus lõpulõigus. Drastilisemad on need juhtumid, kus kirjutajal puudub adekvaatne taustatunnetus, nii et tekstide dialoogilise ja kontekstuaalse tõlgenduse asemel valmib n-ö oma asja ajav piiratud kirjatöö. Vahel vajab täpsustamist mõni kirjandusteaduslik mõiste, mida tekstis läbivalt kasutatakse, või mõni teoreetiline seisukoht, millele analüüs toetub.

Esseekirjutuse lisaprobleemid on mitmesugused stiilivääratused ja õigekeelsusvead, mida saaks hoolsama viimistlemise käigus vältida. Pahatihti tuleb esseedes juhtida tähelepanu konarlikule ja kohmakale sõnastusele, vigasele lausestruktuurile või stiililistele ebakõladele (nt oleviku- ja minevikuvormi ebajärjekindel kasutus, kantseliitlikud keelendid). Kohati võib puududa lausetevõi lõikudevaheline sidusus, üleminekud on järsud või harali. Ka interpunktsioonivigadest ei ole esialgu prii ükski esseetoorik.

Mõnikord pole essee lõppu lisatud korrektselt vormistatud allikaloendit või pole nendele allikatele teksti sees korralikult viidatud. Soovida jätab ka alustekstidest nopitud tsitaatide kasutus: need on valesti vormistatud või arutluskäiguga sidumata. Samuti on sobiva pealkirja leidmine mõnikord unarusse jäetud. Ajal, mil tudengite uus põlvkond harrastab twitterlikke lühisõnumeid, võib pikema, s.o 2000sõnalise kirjatöö nõue juba üle jõu käivaks osutuda.

Mis osas eespool nimetatud kitsaskohad (vrd Blau, 2003, lk 152-154) üliõpilaste endi ettekujutustes ja arusaamades ilmnevad, selgub allesitatud küsitluse kokkuvõttest. 


\section{Üliõpilaste küsitlus}

Et saada usaldusväärset infot, tuleb tegevusuuringu käigus rakendada rohkem kui ühte andmekogumisstrateegiat (Dana, 2016, lk 47-48). Kuigi praegusel juhul keskenduti tegevusuuringus eeskätt üliõpilasesseede tagasisidele, st õppejõu kommentaaride kvalitatiivsele analüüsile, oli uurimisprobleemi täpsustamiseks vaja koguda õppijatelt infot nende varasema kirjutamiskogemuse kohta.

Tegevusuuringu raames küsitleti üliõpilasi kursuse alguses kirjalikult, et süsteemselt välja selgitada, milline on nende ettekujutus akadeemilise essee nõuetest ja mis raskusi on nad essee kirjutamisel kogenud. Kahe avatud küsimusega kvalitatiivse lühiküsitluse kaudu, millele vastasid paari viimase aastakäigu õppijad (kokku 38 üliõpilast), püüti muu hulgas kindlaks teha, kas akadeemilise essee kirjutamise raskused tulenevad valedest arusaamadest ja ebaselgetest nõuetest või on põhjus vähene kirjutamiskogemus, mis pärsib kvaliteetsemat lõpptulemust.

Vastustest küsimusele „Milline on Sinu ettekujutus akadeemilisest esseest?“ selgub, et üliõpilaste arusaamad ainealasest esseest puudutavad vähem või rohkem žanri tekstuaalseid, retoorilisi ja diskursiivseid omadusi. Vastuste korduvat sisumustrit silmas pidades on üliõpilaste arvamused induktiivselt jagatud nelja rühma, mida järgnevalt näitlikustavad vaid mõned representatiivsed repliigid.

- Arvamused oma- ja alusteksti suhetest

- Kirjandusteaduslik essee peaks avama analü̈sitava teose tasandid, peidetud tähendused ja pakkuma tõlgendusvõimalusi.

- Essee ei saa olla kirjandusteoste ümberjutustus, vaid see sisaldab kirjutaja enda tähelepanekuid ja mõtteid.

- Essee peaks esile tooma teose autori seisukohad, kuid neid võib siduda ka teiste arvamustega.

- Arvamused arutlemise võtetest ja teksti sidususest

- Akadeemiline essee peaks olema arutlev ja kriitiline.

- Essee peaks olema tervik, milles käsitletakse võrdlevalt tekstide sarnasusi ja erinevusi.

- Essees peavad olema kõik seisukohad selgitatud ja põhjendatud veenvalt.

- Kirjandusteemalises essees peab kasutama kirjandusmõisteid.

- Arvamused essee eesmärkidest ja ülesehitusest

- Essee võiks olla arusaadav ja huvitav ka neile inimestele, kes pole analüüsitavaid teoseid lugenud.

- Essee on kindla ülesehitusega kavandatud kirjutis, justkui kalaluu, millele tuleb liha juurde kasvatada. 
- Esseel peaks olema kindel eesmärk või suunavad küsimused, millele vastust otsitakse.

- Arvamused essee väljenduslaadist ja keelekasutusest

- Isikupärane stiil on samuti oluline, kuid mõttekäik peab olema selgesti jälgitav ja kirja pandud ilusas eesti keeles.

- Hea essee peab olema kirjutatud elavas keeles, ei tohiks peljata seoseid reaalse ja igapäevaeluga.

- Tuleb jälgida, et iga mõte on esitatud arusaadavalt ning kõik väited on sõnastatud selgelt ja korrektselt.

Vastuste laiem spekter näitab, et kõrgkooliõppurite ettekujutus akadeemilisest esseest on võrdlemisi eklektiline. Üldiselt ollakse seda meelt, et essee peaks esitama teadmisi ja vahendama arusaamist, vastama teemakohastele küsimustele tähendusrikkalt ning isiklikust vaatenurgast. Argumentidele toetuvat ja arutlemisvõtetele rajatud kirjutusviisi repliikides kuigi palju ei rõhutata, küll aga mainitakse korduvalt essee ülesehituse eri aspekte. Peamine lõhe, mis õppejõu kommentaaridest ja üliõpilaste arusaamadest nähtub, on seotud essee argumentatsiooniga: õppejõud rõhub tagasisides argumendikesksusele, kuid tudengid mitte.

Erinevaid ettekujutusi esseežanri omadustest ja kirjutaja identiteedist võib siinkohal põhjendada mitmeti. Esiteks, kultuuriti ja koolkonniti on levinud eri esseetüübid ja kirjutamislaadid, mistõttu võivad sisu-, vormi- ja stiilivariatsioonid olla võrdlemisi suured. Teiseks, eri valdkondades ja õppeainetes, nii üldharidus- kui ka kõrgkoolides, õpetatakse essee kirjutamist erinevalt, mistõttu näivad juhised segadusttekitavad ja nõuded mõnel juhul suisa vasturäkivad (Andrews, 2003, lk 120; Wingate, 2012, lk 145). Kuna essee pole meil kujunenud kanooniliste tunnustega tekstiliigiks, ei saa ühtki üliõpilaste vastustes kõlanud seisukohta lugeda otseselt vääraks. Selge ja üheselt mõistetava arusaama kujundamiseks on vaja eri- ja eksiarvamused seminaris läbi arutada, essee kirjutamise metodoloogilisi aluseid pidevalt rõhutada ning kokkuleppelisi nõudeid korrata.

Vastustes teisele küsimusele „Milliseid raskusi essee kirjutamisel oled ise kogenud?" tulevad esile mitmesugused probleemid, millega üliópilased essee kirjutamisel silmitsi seisavad. Mainitud raskusi, mis järgnevalt on jagatud sisukorduste alusel nelja rühma, illustreerivad siinkohal vaid mõned representatiivsed arvamused. 
- Raskused, mis on seotud kirjutaja enda loovvõimetega

- Kirjandusliku essee puhul on kõige keerulisem kirjutada isikupäraselt ja loominguliselt, nii et teksti oleks huvitav lugeda.

- Keeruline on siis, kui mõtteid ei ole, kui jõuan kirjutamise käigus n-ö surnud punkti. Raske on kirjutada midagi, mis oleks täielikult minu mõte. Tunnen, et ei oska midagi tarka öelda.

- Probleeme tekitab minu enda arvamuse ülekaal, sest kipun ennast loetavaga kergesti seostama ning tahan väljendada oma mõtteid.

- Raskused, mis on seotud alusteksti analüüsi ja tõlgendamisega

- Lugedes võib tihti jääda mõni seik segaseks või seosetuks ning ise loogilise järelduse peale lõpuks ei tulegi.

- Peamine kahtlus: kas minu nägemus teosest on ikka ôige, kas suudan tervet teost hoomata ja mõista?

- Teinekord on raske hoiduda ümberjutustamisest, see aitab ka teksti pikkust kasvatada.

- Raskused, mis on seotud essee teema piiritlemise ja arendamisega

- Kui ma ei tunne analüüsitavate teostega head kontakti, siis on kogu kirjutamisprotsess palju vaevalisem.

- Mulle valmistab raskusi ühele teemale keskendumine, oma mõtted võivad segada teema piirides püsimist.

- Essee osad ei ole omavahel sujuvalt seotud, tekstilõigud on hüplikud.

- Raskused, mis on seotud vormistuse, väljenduslaadi ja keelekasutusega

- Keeruline on leida head ülesehitust, et iga alaosa oleks loogiline ja piisavalt sisukas.

- Kirjutamisel on keeruline valida sobivat stiili, kipun liiga vabalt oma mõtteid kirja panema.

- Kirjutan ehk liiga kiirustades, ei suuda olemasolevaid lauseid paremaks lihvida.

- Natuke ähmane on see essee. Eriti kui ei ole varem kirjutanud.

Nagu vastustest ilmneb, on akadeemilise essee kirjutamisel mitmeid murekohti: teoste valik, sobiv teema, pealiskaudsed või hüplikud mõttekäigud, mõttete nappus või üleküllasus, sobimatud tekstinäited, nõrgalt seotud tekstilõigud, ebaloogiline ülesehitus, puudulik viitamine, keeleeksimused ja stiilikonarused, ajanappus (vrd McEwan, 2017). Paljudel juhtudel muretsevad tudengid oma lugemisoskuse, st teksti mõistmise ja analüüsimise oskuste pärast, peamiselt kardetakse kalduda kirjandustekstide väärtõlgendustesse 
või siis jõutakse nende mõistmise võimalustega tupikusse. Mõnes vastuses rõhutatakse ka oma vähest kirjutamiskogemust, väljendatakse oma kartusi ja segadusi. Samuti võib õppijate hulgas olla neid, kellele eesti keel on võõrkeel, mistõttu ladusat kirjutamisoskust pärsib keelebarjäär. Enda tugevat kirjutajaidentiteeti ei toonita ükski vastaja.

Vähesest kirjutamispraktikast tingitud kahtlused vajavad kindlasti kummutamist, et pöörata vastustes ilmnenud puudused kirjutamisprotsessi juhendamise käigus oskusteks, mida noor kirjutaja suudab teadlikumalt rakendada ja arendada. Nii eriseminarides kui ka individuaalse tagasiside käigus tuleb järjepanu täpsustada essee sisu- ja vorminõudeid ning osutada probleemidele, unustamata sealjuures tunnustada õnnestumisi mis tahes nüanssides. Oluline on kogenematuid kirjutajaid rahustada ja julgustada, vähendada nende ärevust ja ebakindlust, aga ka aukartust akadeemiliste tekstide kirjutamise ees. Kindlasti tuleb ümber lükata käibiv väärarvamus, nagu peaks essee vastama vaid aine õppejõu mängureeglitele, ainult tema vaimusilmas terenduvale ideaalile, mis ei ühti tegeliku lõpptulemusega (McEwan, 2017). Isikupärased varjundid ja rikastavad variatsioonid annavad esseežanrile nauditava vabaduse, mida tasub kõrgelt hinnata ja iga autori puhul ka tunnustada.

\section{Kursusesse kavandatud didaktilised muudatused}

Tuginedes nelja õppeaasta kursuseesseede analüüsile ja õppijate arusaamadele akadeemilisest esseest, tehti kursuse „Proosateksti analüüs“ õppetegevustes järgmised ainedidaktilised muudatused.

- Vähendati seminaris käsitletavate lugemistekstide hulka ja mahtu, tehti lugemiseks valikuid ja kursuse ajakavasse vahenädalaid, et jäks rohkem aega tekstidesse süveneda ja kriitiliselt mõelda.

- Koostati seminariks eri eesmärgiga lugemis- ja kirjutamisülesandeid, peamiselt analüüsi- ja tõlgendusülesandeid nii individuaal-, paaris- kui ka rühmatööks; suulised ülesanded olid kombineeritud kirjalikega.

- Pakuti essee kirjutamist ette valmistavaid soovituslikke lisaülesandeid (nt lugemismärkmete tegemine, lugemispäeviku pidamine, teostest tsitaatide valimine, loetu kohta küsimuste ja väidete sõnastamine), mida sai teha interaktiivses õpifoorumis.

- Selgitati kirjalikus juhendis essee kirjutamise eesmärke ja nõudeid, samuti hindamiskriteeriume, algatati didaktilisel vaatmikul põhinev arutelu, juhiti tähelepanu tüüpilistele kirjutamisraskustele, suunati óppijaid oma kirjutamisprotsessi järgmise 6-8 nädala jooksul kavandama. 
- Juhendati essee kirjutamist individuaalse kirjutamiskonsultatsiooni vormis (15 minutit ajagraafiku alusel), jagati soovitusi ja juhiseid ning esitati toetavaid küsimusi.

- Korraldati essee kirjutamine etappide kaupa, anti iga üliõpilase essee esmavariandi kohta kirjalikku tagasisidet ja lepiti kokku töö lõpptähtajas.

- Anti iga üliõpilase essee lóppvariandi kohta kirjalikku tagasisidet, hinnati töid varem koostatud ja läbi arutatud hindamiskriteeriumite abil.

- Koguti üliõpilastelt essee hindamise järel juhendamis- ja kirjutamisprotsessi kohta tagasisidet ning tehti järeldusi oma õpetamise kohta.

Esseekirjutuse seisukohalt on olulised kolm ainedidaktilist tegevust, mille kasulikkuse ja tõhususe üle järgnevalt arutletakse.

\section{Individuaalne kirjutamiskonsultatsioon}

Oluline viis tõhustada kirjutamisprotsessi on üliõpilase individuaalne juhendamine suulise konsultatsiooni vormis, mis võimaldab suunamise, nõustamise ja toetamise kaudu kujundada ennastjuhtivat kirjutajat. Individuaalne suuline konsultatsioon kui õppijat aktiveeriv intensiivne meede sobib kirjutamisprotsessi algusfaasi, lubades vahetus suhtluses ja aega säästvalt olla õppejõuga dialoogis (Schillings et al., 2018). Suuline kirjutamiskonsultatsioon tähendab vestlust, mille käigus aine õppejõud usutleb üliõpilast, et saada ettekujutus, kuidas ta valitud teemat avab, mil viisil kirjutamist kavandab ja milliseid võimalikke raskusi aimab. Peale selle saab õppejõud rahulikul toonil vastata õppija küsimustele, jagada selgitusi, klaarida eksiarvamusi ja kummutada kahtlusi ning süstida kirjutajasse suuremat enesekindlust ja -usku. Kuna alati leidub ka neid õppijaid, kelles individuaalne suuline vestlus tekitab ärevust ja ebamugavust (Cartney, 2010), võib alternatiiviks olla üliõpilase ja õppejõu vaheline kirjalik suhtlus sobivas õpifoorumis.

15minutiseks konsultatsiooniks tuleb üliõpilasel läbi mõelda essee fookus, leida loetud teoste võrdlemiseks sobivad paralleelid ja luua kirjatöö esialgne kava. Soovitatavalt võib üliõpilane toetuda lugemismärkmetele, et väljendada oma arusaamist teostest ning sõnastada kandvaid argumente ja kriitilisi seisukohti. Suulisi juhiseid jagades puudutab õppejõud kirjutamisprotsessi eri tahke ehk jälgib, kas teoste mõistmisel on tekkinud põhimõttelisi tõrkeid, milliseid teostevahelisi sarnasusi ja erinevusi on üliõpilasel kavas analüüsida, mis on kavandatava essee juhtküsimused ja põhiväited, kuidas jagada tekstianalüüs sisuliselt loogilisteks alaosadeks, milliseid viitamisega seotud näpunäiteid või tehnilisi soovitusi kirjutaja vajab, milline on kirjutamise ajakava, milliseid erikokkuleppeid tuleks kirjutajaga sõlmida. Suuline konsultatsioon on üliõpilase 
ja õppejõu vaheline dialoog, mis tagab kirjutamisprotsessile kvaliteetse jätku (siinse tegevusuuringu käigus läbisid 15minutise konsultatsiooni 42st viimasel kahel aastal kursusele registreerunud üliõpilasest 38).

\section{Tagasiside essee esmavariandi kohta}

Kirjalikul tagasisidel on võtmeroll akadeemiliste tekstide kirjutamise oskuste omandamisel ja kinnistamisel (Schillings et al., 2018), aga ka üldiste õpistrateegiate täiustamisel (Hattie \& Timperley, 2007). Tagasiside andmine essee esmavariandi kohta muudab kogu kirjutamisprotsessi tunduvalt paindlikumaks ja nüansirikkamaks, suunab kirjutajat vastutustundlikult ja ennastjuhtivalt õppima, et tõhusamate õpistrateegiate abil kvaliteetsema lõpptulemuseni jõuda. Õppejõu tagasisidet hinnates kogeb tudeng, et kirjutamine ei ole kaugeltki ühekordne suletud tegevus, vaid etapiviisiline avatud protsess (Medina, 1994; Stott, 2001), kus ajaressurssi kavandades tuleb aktiivselt ja kaalutletult tegutseda. Tagasiside aitab tudengil hinnata oma töö kvaliteeti ja kujundab pädevust teha muudatuste tegemiseks otsuseid.

Kui tagasisidest essee lõppvariandi kohta kujuneb kardetavasti vaid hinde kommentaar, mida üliõpilane ei pruugi isegi lugeda, siis kommentaarid essee esmavariandi kohta annavad üliõpilasele võimaluse teha parandusi ja täiendusi, et kinnistada kirjutamisoskusi. Kirjutaja võib veenduda oma ideede jõukohasuses ja kavatsuste paikapidavuses, ka selles, mida temalt oodatakse ja mis kriteeriume hindamisel arvestatakse. Kui tudengil ei ole piisavalt akadeemiliste tekstide kirjutamise kogemust, siis võib esseežanris kirjutamine olla mõnevõrra võõras, mistõttu on metoodiline juhendamine mõnel juhul ainuvõimalik lahendus. Ühtlasi võib eeldada, et vaheetapis antud tagasiside motiveerib tudengit pingutama, et pälvida parem lõpphinne. Kuna esseežanris kirjutamine aitab omal moel kaasa õpinguid lõpetavale uurimistööle, on õppejõu kommentaaridest abi ka edasiseks akadeemiliseks kirjatööks (Wingate et al., 2011).

Essee kohati hajusad ja vastuolulised omadused tingivad olukorra, kus õppejõud peab oma kommentaarides selgitama kirjutamisülesandega seotud ootusi, et suunata kirjutaja kindlamale rajale. Kuna küsitavusi ja eksimusi võib esmavariandis olla mitmesuguseid, on kirjutajale abiks õppejõu täpsustavad küsimused ja konkreetsed suunised. Liiga üldised, ebamäärased või elliptilised kiirrepliigid (nt „ebaloogiline mõte“, „arusaamatu ülesehitus“, „sidumata tsitaat"), aga ka arusaamatust või kaheldavust tähistavad küsimärgid ei võimalda kirjutajal ennast kriitiliselt hinnata ega tööd redigeerida (Beach \& Friedrich, 2006). Kujundav tagasiside peab olema põhjendav ja selgitav, võimaldama hinnata töö tugevaid ja nõrku külgi tasakaalustatult. 
Tagasiside andmise mõju on seegi, et üliõpilased õpivad konstruktiivset kriitikat vastu võtma ja väärtustama, täiendades oma kirjatööd mentori soovituste ja ettepanekute toel. Avarapilguline ja süvenemist pakkuv teemakäsitlus tekitab omakorda sünergiat, ärgitades ka õppejõudu sisulistes küsimustes kaasa mõtlema ja kirjutajaga dialoogi astuma. Motivatsiooni hoidmiseks peab aine õppejõud kirjutajat ka tunnustama, nt huvitavate ideede, leidlike seoste, õnnestunud tõlgenduste eest. Selgitavad märkused nii esseeteksti sees kui ka kokkuvõtvad soovitused ja juhised teksti lõpus on hindamatu meede, mis aitavad kujundada enda kirjutamisoskusi hindavat ja täiustavat esseisti. Mõistagi vajab edaspidi uurimist, mil määral suudavad üliõpilased õppejõu märkusi kirjatöö parendamisel arvestada.

\section{Tagasiside essee lõppvariandi kohta}

Essee lõppvariant, mida hinnatakse eristavalt, annab tunnistust kirjutaja soovist kõrvaldada varasemad puudujäägid ja parandada oma kirjutamisoskust parema lõpptulemuse nimel. Kuigi alati võib kirjutajalt eeldada mõningast intellektuaalset varu, realiseeruvad kirjutaja võimed ja oskused eeskätt õppejõule hindamiseks saadetud lõppvariandis. Tagasiside andmine essee lõppvariandi kohta on üldjuhul vaid hinde kommentaar, mitte enam dialoogiline sekkumismeede.

Essee lõppvariandi hindamisel peab õppejõud lähtuma kindlatest kriteeriumitest, mis on tudengitele hindamisjuhendis teada antud (Fernsten \& Reda, 2011). Kursusel „Proosateksti analüüs“ on need kriteeriumid ${ }^{3}$ järgmised:

1) alustekstide ja nende taustade tundmine;

2) võrdleva analüüsi valdamine ja tulemuslik rakendamine;

3) teemakäsitluse veenvus, loogilisus ja terviklikkus, mõtlemise iseseisvus ja isikupärasus;

4) argumentide ülesehitus, sh näited, seosed, põhjendused, järeldused;

5) teksti loogiline ülesehitus, liigendamine alaosadeks ja lõikudeks;

6) alustekstide ja sekundaarallikate kasutamine, neile viitamine;

7) kirjandusteaduslike mõistete ja teoreetiliste seisukohtade kasutamine;

8) õigekiri, sobiv ja ladus stiil;

9) korrektne vormistus.

Nende kriteeriumite arvestamisega tulid tudengid üle- ja ümberkirjutamise käigus valdavalt edukalt toime. Maksimumist madalama hinde saanud esseede puudusteks olid veel mõnevõrra hajus ja harali arutlusliin, pealiskaudne ja

Essee hindamise kriteeriume on oma artiklites käsitlenud paljud autorid (vt nt Andrews, 2003; Harrington et al., 2006). 
lihtsustav teemakäsitlus, mis ei mõjunud veenvalt, terviklikult ega isikupäraselt. Seda tüüpi puudusi on mõistagi keerulisim kõrvaldada, sest sõltub see ju paljuski kirjutaja ainetundmisest, maailmavaatelisest küpsusest, tunde- ja mõttemaailma rikkusest, mida ühe kirjutamisülesandega kuigi palju kõigutada ei õnnestu.

Nagu kursuseesseede lõplik ülevaatus kinnitas, paranes tekstiloome kvaliteet võrreldes esmavariandiga kõigi hindamiskriteeriumite puhul märgatavalt. Üldjoontes said üliõpilased esmavariandi probleemidest aru, nad võtsid õppejõu soovitusi ja ettepanekuid arvesse ning tegid parandusi. Nii nagu mitmed uuringud tõendavad (nt Hendry, Armstrong, \& Bromberger, 2012), tagas mitmeetapiline tagasiside ka „Proosateksti analüüsi“ esseedele märgatavalt parema lõpphinde.

\section{Üliõpilaste tagasiside essee juhendamise kohta}

\section{Küsitlus kirjutamisprotsessi järel}

Essee eristava hindamise järel küsis aine õppejõud üliõpilastelt kirjalikku tagasisidet, et hinnata essee juhendamise protsessi tõhusust ja tudengite tekstiloomeoskuste paranemist. Esitati kaks avatud küsimust: 1) Kuidas hindad esseekirjutamise juhendamist sellel kursusel? Nimeta konkreetseid detaile juhendamise kvaliteedi ja protsessi kohta; 2) Mida essee kirjutamise protsessist kõige rohkem óppisid? Nimeta endale kasulikke või huvitavaid aspekte. Kirjalikke vastuseid laekus 18lt viimase kahe aastakäigu üliõpilaselt.

Esimese küsimuse vastusteks kirjutasid tudengid muu hulgas järgmisi repliike.

- Suuline juhendamine aitas mul kahtlustest üle saada ja oma ideega edasi liikuda, väga vajalik samm õppejõu poolt.

- Tagasisidest mustandile sain kasulikku infot, mille peale ma ise ei tulnud. Juhendaja aitas värskeid mõtteid leida ja teemat teise pilguga vaadata.

- Pärast essee esmavariandi esitamist lugesin valitud teosed veel kord läbi, tegin märkmeid, et esseed täiendada.

- Kuna óppejõud andis esseele põhjalikku tagasisidet, oli sellest óppida väga palju. Tagasiside järel oli ärevust vähem.

- Õppejõud selgitas, kuidas ma saaksin oma teksti liigendada, kasutada alapealkirju ja tekitada lõike, enne seda oli mu tekst mingi arusaamatu kamakas.

- Hurraa, essee esmavariant tuli tagasi põhjalike kommentaaridega, millest oli selgelt näha - see oli üleni läbi loetud! Mitte iga päev seda Tartu ülikoolis ei juhtu. Üliõpilaste vastustest selgus, et etapiviisiline kirjutamisprotsess pakkus neile nii teoreetilisi lähtekohti kui ka praktilisi näpunäiteid, seega said õppijad 
selgema ettekujutuse akadeemiliste tekstide kirjutamise võlust ja valust. Meeldivalt palju mainiti vastustes suulise konsultatsiooni ja essee esmavariandi tagasisidestamise positiivset mõju kirjutamisoskusele. Üliõpilased nägid kirjalikku tagasisidet kui kasulikku ja väärtuslikku õpistrateegiat, mis tõi esile nii nende tugevaid kui ka nõrku külgi. Positiivne oli nende arvates veel see, et tagasiside puudutas ka essee sisulisi tahke: ärgitas alustekste hoolsamalt lugema, julgustas kriitiliselt mõtlema ja innustas teemasse süvenema. Ühtlasi said klaariks nõuded, mida esseelt oodatakse, ja selginesid hindamiskriteeriumid. Vähemalt ühe üliõpilase arvates polnud tagasisidest kasu mitte ainult „Proosateksti analüüsi“ essee kirjutamisel, vaid ka edasiste akadeemiliste kirjutamisülesannete tegemisel. Miinusena mainiti, et etapiviisiline kirjutamine nõuab tavapärasest palju rohkem aega.

Järelküsitluse teisele küsimusele vastasid üliõpilased muu hulgas järgmist.

- Õppisin esseed teadlikumalt kavandama ja süsteemi looma. Mõtlen rohkem sellele, mis on kõige tähtsam, mida öelda tahan.

- Oskan nü̈̈d paremini olulisi mõtteid rõhutada ja kasutan mõtete täpsustamise ja ümbersõnastamise taktikat.

- Kasutan edaspidi arutlemisvõtteid, millest ma varem ei teadnud, jälgin, et essee põhiväited saaks paika.

- Óppisin oma tööd üle lugema ja seda kriitilise pilguga vaatama. Varem ei märganud ma oma essees selliseid vigu nagu nüüd.

- Püüan edaspidi segasevõitu targutamist vältida ja oma mõttelónga ohjata, kõike, mis pähe tuleb, pole tarvis kirja panna.

- Kuna kohmakad laused ja arusaamatu sõnastus ei tule kirjutamisel kasuks, siis kulutasin üsna palju aega stiilile.

- Väga raske on juba kirja pandud lauseid muuta, kuid püüan seda edaspidi teha, et mõte oleks selgem.

Vastused kinnitasid, et õppejõu konstruktiivne sekkumine suunas neid oma kirjatööd vähem või rohkem ümber töötama, mida kõik üliõpilased ka tegid. Kõlama jäi tõik, et kirjutajad õppisid argumente hoolikamalt sõnastama, valitud teostesse üksikasjalikumalt süüvima, alustekste mõttekalt tsiteerima, jõulisemaid üldistusi ja põhjendatud järeldusi tegema, parajal määral sekundaarmaterjali juurde lugema (nt kirjandusloolise tausta või teoste retseptsiooni kohta). Teisisõnu õpiti oma seisukohti selgemalt ja ausamalt esitama, vältima ebamäärasust ja pretensioonikust. Essee asetamine n-ö luubi alla nõudis õppijalt vastutustundlikku suhtumist, välistas võimaluse kergel käel loobuda või nõrga tulemusega hoolimatult leppida. Kirjutamise käigus õpitu võib kokku võtta väärtuslike soovitustena juba järgmiste aastakäikude õppijatele, kes kirjutama asudes tunnevad end ebakindlalt või ärevalt. 


\section{Tagasiside õppeinfosüsteemis}

Üks õppetöö tulemuslikkust peegeldavaid näitajaid on üliõpilaste tagasiside Tartu Ülikooli õppeinfosüsteemis (ÕISis). Muudatused esseekirjutamise didaktikas mõjutasid positiivselt kogu „Proosateksti analüüsi“ kursust: kui 2015. ja 2016. aasta kevadsemestril olid kursuse keskmised hinded vastavalt 3,45 ja 3,5, siis kahel viimasel aastal tõendavad õppijate suuremat rahulolu hinded 4,75 ja 4,55. Positiivset hinnangut kirjutamisprotsessi juhendamisele kinnitavad ka ÕISi laekunud kommentaarid, milles tõsteti eriti esile ülesannete kohta antud tagasisidet.

Kuna essee põhjal kujuneb kursuse lõpphinne, on üliõpilaste akadeemilised tulemused otseselt seotud essee kirjutamiseks tehtud pingutustega. Positiivse suundumusena kasvas kahel viimasel aastal märgatavalt „suurepäraste“ ja „„äga heade“ soorituste arv, peaaegu täielikult taandusid „rahuldavad“ ja „kasinad“ tulemused: esseede keskmine hinne paranes muudatuste järel vastavalt 3,6 ja 3,1 pealt 4,2 ja 4,1 peale. Tähelepandavalt vähenes kursuse lõpuessee esitamata jätnud üliõpilaste arv: 2015. ja 2016. aastal oli neid kokku 20, kahel viimasel aastal vaid viis. Kuigi ÕISis kajastuv tagasiside on mõnevõrra tendentslik, loob see eri aastate lõikes kursuse dünaamikast siiski arvestatava kuvandi.

\section{Järeldused ja soovitused}

Tegevusuuringuga püüti lahendada essee kirjutamisega seotud praktilisi probleeme kirjanduse eriala bakalaureusekursusel. Lähtematerjaliks olid 78 essee analüüsiandmed, mis andsid õppejõule ettekujutuse esseekirjutamise põhipuudustest, korduvatest eksimustest ja tüüpvigadest. Üliõpilaste eelküsitlus, milles uuriti nende arusaamu esseežanrist, veenis, et õppijatel puudub ühene ettekujutus esseežanri omadustest ja nad seisavad silmitsi mitmesuguste raskustega.

Kursuse arendamisel rakendati kahte essee kirjutamist toetavat didaktilist sekkumismeedet: individuaalset suulist konsultatsiooni ja kirjalikku tagasisidet essee esmavariandi kohta. Mõlemad meetmed andsid kirjutajale võimalikult objektiivse pildi tema isiklikest arenguvajadustest ja -võimalustest. Õppejõu asja- ja jõukohane sekkumine edendas kahe osalise vahelist hariduslikku dialoogi ning kujundas ühtlasi ennastjuhtivat õppijat.

Üliõpilaste järelküsitlusest ilmnes, et mõlemad meetmed tõid selgust essee hindamise kriteeriumitesse ja peegeldasid õppejõu ootusi. Suuline konsultatsioon ja kirjalik tagasiside essee esmavariandi kohta andsid parema ettekujutuse akadeemiliste erialatekstide kirjutamisest ning parandasid essee kirjutamise oskusi kõigis veakategooriates ja pädevusvaldkondades. Positiivseid muutusi 
kinnitas omakorda õppejõu tagasiside essee lóppvariandi kohta, mis veenis, et kõik õppijad olid oma esseed täiendades-parandades õppejõu soovitusi ja ettepanekuid vähem või rohkem arvestanud ning oma edusamme teadvustanud. Üliõpilaste meelest parandasid need kaks sekkumismeedet kursuse kvaliteeti, ühtlasi tõusis nende toel oluliselt kursuse lõpuhinnete keskmine.

Tegevusuuring näitas, et individuaalset kirjutamisprotsessi tuleb vaadelda palju komplekssemalt, arvestades muu hulgas õppijate varasemat kirjutamiskogemust, arusaamu žanrinõuetest, võimaluse korral ka nende sotsiokultuurilist tausta, mida siinne uuring ei puudutanud. Uuringuandmetest võib järeldada, et esseekirjutamist on otstarbekas õpetada etapiviisilise protsessina, mis hõlmab loogiliselt järjestatud tegevuste rida, alustades võrdluseks sobivate tekstide leidmisest ja lugemisest, materjali kogumisest ning lõpetades kirjatöö viimistlemise ja toimetamisega. Kasuks tuleb see, kui koos tudengitega läbi arutada esseekirjutamise etapid (vt Luks, 2007).

Õppejõu ülesanne on toetada kirjutamisprotsessi, anda tudengitele piisav ja selge ettekujutus esseežanri omadustest ja konkreetsetest nõuetest. Õppejõud kui institutsiooni salaagent vastutab selle eest, et üliõpilastele vahendataks akadeemiliste tekstide kirjutamise parimaid tavasid. Õppejõu roll on seega suunata kirjutajat toetavate märkuste kaudu oma tööd täiendama ja parandama, teksti eesmärgistatult, kompaktselt ja süsteemselt üle ja läbi kirjutama. Ühtlasi peegeldab õppejõu konstruktiivne tagasiside kirjutaja metakognitiivseid oskusi, millest üks tähtsaimaid on oskus ise oma kirjutamistegevust mõtestada ja hinnata.

Siinse uuringu kontekstis saab päevakohaseks tõdemus, et ebapiisavad, ähmased või vasturääkivad juhendid mõjutavad märgatavalt esseede kvaliteeti (vt ka Lea \& Street, 1998; Wingate, 2012). Seepärast on oluline, et õppejõud deklareeriks essee nõudeid arusaadavalt ning pakuks konkreetseid ja tähendusrikkaid kommentaare. Esseežanri omadustest aitab arusaadava ettekujutuse luua see, kui seminaris arutatakse läbi essee kirjutamise juhend, sh hindamiskriteeriumid, et vältida eksiarvamusi ja vääritimõistmist. Peale juhendi võiks esseekirjutuse põhitõdesid ja võtmeetappe illustreerida mõni kokkuvõttev skeem või joonis (vt Medina, 1994, lk 6; Wingate, 2012, lk 153), mis on abiks eeskätt visuaalse õpistiiliga õppijatele, et korrastada ja meelde jätta oskusliku kirjutamise nippe. Selleks sobib hästi ka vaatmik, kus info visuaalset esitamist võiks eelistada verbaalsele jutustamisele.

Et vältida ettearvatavaid probleeme, on otstarbekas õppijatega koostada ja läbi arutada mõned metoodilised kontrollküsimused, mis aitavad vajalikele tahkudele tähelepanu pöörata. Samuti võib õppijatele koostada essee tüüpvigade nimekirja, kus selgitatakse lühidalt iga vealiigi olemust (vt Norton, Clifford, Hopkins, Toner, \& Norton, 2002, lk 117). Mõistagi pole kunagi ülearune harjutada üliõpilastega essee kirjutamise osaoskusi väiksemate 
kirjutamisülesannete kaupa (vt Fernsten \& Reda, 2011, lk 174). Edaspidi võib katsetada alternatiivseid võtteid, nt lasta lugeda ja kujundavalt hinnata kaasóppijate esseid, et üliõpilased mõistaksid žanritavasid ja märkaksid tüüpvigu, või proovida essee kirjutamist ette valmistada paaristööna.

\section{Kokkuvõte}

Pole välistatud, et essee on kõrgkoolipedagoogika tarbeks liiga ebaselge ja laialivalguv žanr, mis on oma kunagise akadeemilise prestiiži minetanud. 21. sajandi tekstiloome ei soosi pikki formaate, mis pakuvad vaid teoreetilisi seisukohti ja formaalseid analüüse, vaid eelistab praktilise eesmärgiga lühemaid tekste, nt vikiartikkel, kokkuvõte, arvustus. Esseežanri kõrval on nüüdisajal menukaks osutunud mitmesugused loovkirjutamise ülesanded, kuid alternatiive akadeemiliste tekstide kirjutamisele võib leida teisigi, nt sokraatiline dialoog, narratiivne, omaelulooline ja metafoorne kirjutamine. Siiski võib loota, et esseežanri paindlikkuses ja avatuses peitub perspektiiv, millele kõrgkoolipedagoogika saab anda väärtusliku praktilise väljundi.

Akadeemiline essee pakub kirjutajale ühelt poolt aristokraatlikku vabadust, teiselt poolt sätestab rustikaalsed ettekirjutused, millest ei saa mööda hiilida. Seda tasakaalu loomingulise vabaduse ja ootuspäraste nõuete vahel peabki nüüdisaegne kirjutamisõpetus taktitundeliselt timmima. Kirjutamisõpetuse universaalseid nõuandeid on suhtuda kirjutamisse kui mõtlemisprotsessi (Fernsten \& Reda, 2011). Üliõpilase seisukohalt ei tohiks akadeemiliste tekstide kirjutamine olla automaatne liinitöö, mis kopeerib etteantud formaati ja päädib ettearvatava palgatšekiga, vaid see on pikaajaline intellektuaalne investeering, mis peaks kirjutajale pakkuma rahulolu.

Nii nagu essee kirjutamine, on ka selle juhendamine aega ja kannatust nõudev protsess, mida on metoodiliselt kasulik jagada väiksemateks töölõikudeks. Õppejõul peab olema professionaalset pilku, et suunata tudengite lugemisvalikut, tutvuda nende märkmetega loetu kohta, selgitada essee žanrinõudeid, jagada kirjutamiseks nippe ja nõuandeid, juhtida lugemisarutelusid ja kirjutamisülesandeid seminaris, viia läbi individuaalset kirjutamiskonsultatsiooni, reageerida ootamatutele kirjutamistõrgetele, tagasisidestada kirjalikult essee esma- ja lõppvarianti, hinnata objektiivselt lõpptulemust, tunnustada üliõpilasi õnnestumiste ja eneseületuste eest. Kuna tudengite kirjutamisoskus on sedavõrd erinev, on individuaalne etapiviisiline juhendamine parim viis suurendada uue põlvkonna õppijate lugemis- ja kirjutamisvõimekust.

Õppejõu roll on kujundada aktiivselt õppija-õppejõu õpidialoogi, rakendada võimaluse korral ka kollegiaalset (triloogilist) õpitegevust, milles osalevad 
teisedki sama rühma õppijad. Tänapäeval eeldab professionaalse õppejõu kuvand, et ta enda ainedidaktilist pädevust rakendades arendaks oma refleksiivset kompetentsust, mis tähendabki oskust mõtestada oma õpetamistööd ja hinnata iseennast õpiprotsessi suunajana, ja oleks valmis tegema õpetamises muudatusi. Lisatasuks meisterlikule õppejõule on õnnelikud üliõpilased, kes tunnevad heameelt ja rahulolu oma õnnestumistest.

Artiklis kajastatud tegevusuuringuga tähtsustati õppejõu rolli akadeemilise essee kirjutamisel, rõhutati oskust kasutada erinevaid didaktilisi sekkumismeetmeid, et õppijatele jagada, ent neilt ka ise vastu võtta soovitusi ja nõuandeid. Need positiivselt tunnetatud meetmed olid 1) individuaalne kirjutamiskonsultatsioon suulise usutlusena, 2) kirjalik tagasiside essee esmaja lõppvariandi kohta ning 3) tagasiside üliõpilastelt eel- ja järelküsitlusena. Oma tegevuses oli õppejõud kui üliõpilaste õpienergia suunaja ja motivatsiooni hoidja parajalt kriitiline, samas osavõtlik ja pühendunud, et kogu seda töömahukat protsessi hallata. Vajalikud didaktilised muudatused kursuse õppeprotsessis, ka õppejõu nõudlik suhtumine üliõpilaste juhendamisse aitasid parandada eesti kirjanduse eriala kursusel akadeemilise essee kirjutamise oskusi ja loodetavasti suurendada esseežanri prestiiži kõrgkoolipedagoogikas.

Esseekirjutuse didaktika edasine uurimine kõrgkoolipedagoogika kontekstis on oluline. Kvalitatiivseid meetodeid rakendades võiks veelgi ulatuslikumalt ja põhjalikumalt uurida kirjutamisprotsessi tagasiside andmise etappe, näiteks seda, mis tingimustel ja kui tõhusalt toetab individuaalne suuline konsultatsioon kui dialoogiline sekkumismeede akadeemiliste tekstide kirjutamist, või vaadata veelgi detailsemalt seda, kuidas tudengid mõistavad ja tõlgendavad essee esmavariandi kohta antud tagasisidet ning mil määral need kommentaarid nende kirjutamisoskusi ja -hoiakuid tegelikult muudavad ning hindega korreleeruvad.

\section{Kasutatud kirjandus}

Andrews, R. (2003). The end of the essay? Teaching in Higher Education, 8(1), 117128. https://doi.org/10.1080/1356251032000052366

Beach, R., \& Friedrich, T. (2006). Response to writing. In C. A. MacArthur, S. Graham, \& J. Fitzgerald (Eds.), Handbook of writing research (pp. 222-234). New York: Guilford Press.

Blau, S. D. (2003). The literature workshop: Teaching texts and their readers. Portsmouth: Heinemann.

Cartney, P. (2010). Exploring the use of peer assessment as a vehicle for closing the gap between feedback given and feedback used. Assessment \& Evaluation in Higher Education, 35(5), 551-564. https://doi.org/10.1080/02602931003632381 
Carvalho, J. B. (2005). Writing as a learning tool: A new conception of writing in the Portuguese curriculum. In M. Pandis, A. Ward, \& S. R. Mathews (Eds.), Reading, writing, thinking. Proceedings of the 13th European conference on reading (pp. 183187). Newark: International Reading Association.

Cochran-Smith, M., \& Lytle, S. L. (2009). Inquiry as stance: Practitioner research for the next generation. New York: Teachers College Press.

Dana, N. F. (2016). Süvitsi tegevusuuringust. Uuriva ópetaja teejuht. Tartu: Tartu Ülikooli Kirjastus.

Fairclough, N. (1992). Discourse and social change. Cambridge: Polity Press.

Fernsten, L. A., \& Reda, M. (2011). Helping students meet the challenges of academic writing. Teaching in Higher Education, 16(2), 171-182.

https://doi.org/10.1080/13562517.2010.507306

Harrington, K., Elander, J., Lusher, J., Norton, L., Aiyegbayo, O., Pitt, E., ... \& Reddy, P. (2006). Using core assessment criteria to improve essay writing. In C. Bryan \& K. Clegg (Eds.), Innovative assessment in higher education (pp. 110119). Publisher: Routledge Falmer.

Hattie, J., \& Timperley, H. (2007). The power of feedback. Review of Educational Research, 77(1), 81-112. https://doi.org/10.3102\%2F003465430298487

Hendry, G. D., Armstrong, S., \& Bromberger, N. (2012). Implementing standardsbased assessment effectively: Incorporating discussion of exemplars into classroom teaching. Assessment \& Evaluation in Higher Education, 37(2), 149-161. https://doi.org/10.1080/02602938.2010.515014

Hounsell, D. (1997). Contrasting conceptions of essay-writing. In R. Marton, D. Hounsell, \& N. Entwistle (Eds.), The experience of learning: Implications for teaching and studying in higher education (pp. 106-125). Edinburgh: Scottish Academic Press.

Johns, A. (2008). Genre awareness for the novice academic student: An ongoing quest. Language Teaching, 41(2), 237-252. https://doi.org/10.1017/S0261444807004892

Kathpalia, S. S., \& Heah, C. (2008). Reflective writing: Insights into lies beneath. RELC Journals, 39(3), 300-317. https://doi.org/10.1177/0033688208096843

Lea, M., \& Street, B. (1998). Student writing in higher education: An academic literacies approach. Studies in Higher Education, 23(2), 157-172. https://doi.org/10.1080/03075079812331380364

Lepajõe, K. (2011). Kirjand kui tekstiliik. Riigieksamikirjandite tekstuaalsed, retoorilised ja diskursiivsed omadused (doktoritöö). Tartu: Tartu Ülikooli Kirjastus.

Luks, L. (2007). Sissejuhatus. L. Luks (koost.), Filosoofiakunst. Eesti Kunstiakadeemia tudengite esseede kogumik (lk 9-17). Tallinn: Eesti Kunstiakadeemia.

McEwan, M. P. (2017). The essay as a lens on transition to the university: Student and staff perceptions of essay writing. International Journal of Teaching and Learning in Higher Education, 29(3), 511-523.

Medina, S. L. (1994). Teaching academic essay writing: Accelerating the process. Bloomington: Indiana University.

Norton, L. S. (1990). Essay-writing: What really counts? Higher Education, 20(4), 411-442. https://doi.org/10.1007/BF00136221 
Norton, L. S. (2009). Action research in teaching and learning: A practical guide to conducting pedagogical research in universities. London: Routledge.

Norton, L. S., Clifford, R., Hopkins, L., Toner, I., \& Norton, B. (2002). Helping psychology students write better essays. Psychology Learning and Teaching, 2(2), 116126. https://doi.org/10.2304/plat.2002.2.2.116

Norton, L. S., \& Norton, B. (2001). Essay feedback: How can it help students improve their academic writing? International Conference of the European Association for the Teaching of Academic Writing across Europe (pp. 1-17). Groningen, Netherlands, June 18-20.

Paltridge, B. (2004). Academic writing. Language Teaching, 37(2), 87-105. https://doi.org/10.1017/S0261444804002216

Samraj, B. (2004). Discourse features of the student-produced academic research paper: Variations across disciplinary courses. Journal of English for Academic Purposes, 3(1), 5-22. https://doi.org/10.1016/S1475-1585(03)00053-5

Schillings, M., Roebertsen, H., Savelberg, H., \& Dolmans, D. (2018). A review of educational dialogue strategies to improve academic writing skills. Active Learning in Higher Education. https://doi.org/10.1177/1469787418810663

Stott, R. (2001). The essay writing process. In R. Stott, A. Snaith, \& R. Rylance (Eds.), Making your case: A practical guide to essay writing (pp. 36-58). Harlow: Pearson Education Limited.

Sultan, N. (2013). British students' academic writing: Can academia help improve the writing skills of tomorrow's professionals? Industry \& Higher Education, 27(2), 139-147. https://doi.org/10.5367/ihe.2013.0145

Tynjala, P., Mason, L. H., \& Lonka, K. (2001). Writing as a learning tool: An introduction. In P. Tynjala, L. H. Mason, \& K. Lonka (Eds.), Writing as a learning tool: Integrating theory and practice (pp. 7-22). Dordrecht: Kluwer Academic Press.

Wingate, U. (2012). 'Argument!' helping students understand what essay writing is about. Journal of English for Academic Purposes, 11(2), 145-154. https://doi.org/10.1016/j.jeap.2011.11.001

Wingate, U., Andon, N., \& Cogo, A. (2011). Embedding academic writing instruction into subject teaching: A case study. Active Learning in Higher Education, 12(1), 69-81. https://doi.org/10.1177/1469787410387814 


\title{
The process of essay writing in a literature course: the student's views and the tutor's feedback
}

\author{
Andrus Org ${ }^{\text {al }}$ \\ ${ }^{a}$ Institute of Cultural Research, University of Tartu
}

\begin{abstract}
Summary
Writing academic texts is an inevitable component of contemporary higher education; writing in a more specific sense is an indispensable method when teaching a particular subject (Blau, 2003). As a species of text, essay-form is an integral piece of writing in which one expresses in depth his/her opinions or feelings on a particular subject. In higher education teaching, essay-form has been used mainly as an individually graded writing task, which enables students to align their own subjective points of view to more general philosophical or scientific perspectives. For this type of academic or English style essay, it is common to have a rather personal discursive overall mood, critical and argumentative perspective, and stylistic comprehension. While the essay, in its traditional form, involves logic, dialectics, and rhetoric, it still enables students to put forward their own personal views as well as to interpret the variety of generic features of the essay-form in a more general manner.

Whilst essay writing is indeed a highly popular genre in higher education practises, it has not gained substantial prestige in the hierarchy of scientific texts, probably due to the fact that, as a genre, its limits and inner attributes are often unclear (Wingate, 2012). Writing a good quality essay demands both knowledge and experience, which fledgling writers often lack (Hounsell, 1997). Since students' views and expectations vary considerably from that of their tutors' in regards to the essay genre (Andrews, 2003; McEwan, 2017; Wingate, 2012), the task of academic essay writing should not be considered as obvious or self-explanatory in any university course but, instead, should be integrated to those disciplines, which expect and require academic text writing (Wingate et al., 2011). When enrolling in a new course, young students expect clearly laid out rules and precise tutor guidance (McEwan, 2017), which, as involving and supporting measures, should bring the whole writing process into focus and shape all writing competences integrally.
\end{abstract}

Institute of Cultural Research, University of Tartu, Ülikooli 16, 51003 Tartu, Estonia; andrus.org@ut.ee 
The aim of this article is to focus on the methodological problems arising from academic essay writing as a piece of discursive reasoning from the perspective of teaching writing. The article is based on action research conducted at the Cultural Institute of the University of Tartu. The research involves the BA course of Estonian literature, entitled "Analysing Prose" and its developmental work over the last four years (2015-2018), which was strongly motivated by the Good Teaching grant from the University of Tartu. The main problem that needed addressing with the "Analysing Prose" course had to do with the quality of essay writing as a specimen of academic text. Since the students experienced great methodological and subject driven difficulties in writing their essays, the teacher had to make several changes in the didactics of the subject. In addition, a variety of questions arose concerning teaching writing, to which we sought answers in this action research:

1) what are the main methodological problems in essay writing;

2) what particular subject didactic measures could help to support essay writing;

3) in what ways could we develop academic essay writing skills even further?

The aim of the action research was to establish ways in which university teachers could more effectively assist students in their essay writing and improve the quality of their supervision. This is unavoidable if we are determined to improve the academic writing skills and eliminate common shortcomings and mistakes in the writing process.

In order to get a more comprehensive overview, we had to cover both students' and tutors' perspectives in analysing the problems of essay writing. At first we examined the tutor's feedback to 78 essays, and it became clear that the main difficulties in academic essay writing concern various text creation skills: a) choosing appropriate levels of analysis and method; b) overall construction of the text, structure and coherence of particular text segments; c) development of themes, finding arguments, building connections between ideas; d) citing and referencing primary sources, connecting them to one's own ideas; e) phrasing ideas clearly; choosing appropriate and correct language skills.

After this stage, we gathered information from the students as to how they perceive the requirements of academic essay writing and what difficulties they have personally experienced in the essay writing process. In examining their replies, it became apparent that the students' views on academic essay writing are relatively eclectic. The main gulf or dissonance between the tutors' comments and students' views surrounds the argumentation in the essay format: tutors' feedback emphasises the central role of argumentation in the essay, where as students' perspective does not stress this at all: they do not construe their writing predominantly as argument-based. The difficulties that students 
have encountered in essay writing are, in their view, mainly to do with, a) creative skills of a writer, b) analysing and interpreting primary sources, c) limiting and developing the subject of the essay, d) choosing appropriate styles of form, expression and language use. In order to achieve a clear and mutually comprehensive view, the differences need to be discussed thoroughly in seminars and the methodological principles and requirements of essay writing repeatedly voiced.

In the development process of the course, we applied two didactic intervening methods, which support essay writing: $15 \mathrm{~min}$. individual consultation/ tutorial and written feedback to the first drafts of the essays. Both of these methods attempted to give an objective view of certain individual shortcomings and possibilities in order to improve the writing craft. Decisive action from tutors helped to strengthen the educational dialogue between teachers and students and, at the same time, shaped students as self-directed learners. This article directly discusses the positive impact and effectiveness of such intervening methods.

The post-questionnaire of student's views showed that both the above mentioned methods did indeed help students to understand the essay assessment criteria and the tutors' expectations of an academic essay. According to students, the verbal tutorials and written feedback to first drafts of the essays helped to form a clearer understanding of the requirements for specialist academic texts and improved writing skills in all areas and competences. These positive changes were also further confirmed in the tutor's feedback to the last version of the essay, which convinced us that all learners had, to a certain degree, taken into account the suggestions and corrections of their tutors and had been made aware of their progress. Students found that these two intervening measures improved the quality of the course and, in turn, had increased the median of their final grades for the course. The action research showed that individual writing should be approached at a more complex level taking into account, among other things, the students' previous writing experiences as well as their understanding of the requirements of the genre.

The article suggests several didactic approaches on how to make the academic essay writing process more effective. It is evident that the teaching process could be enhance by dividing the subject into smaller phases, consisting of logically ordered actions. Importantly, the phases of essay writing should be thoroughly discussed with students. It is the tutor's task to support the writing process, and offer a sufficient and clear overview of the attributes and the requirements of the essay form. It goes without saying, that the guidelines of the essays and criteria for assessment must be discussed together in seminars in order to avoid misunderstandings and false expectations. In addition to the 
guidelines, some of the core principles and stages of essay writing should be assisted by summarising figures and schema, which is particularly suitable for students prone to a more visual learning style. Poster presentation is also beneficial to this approach in which visual presentation is preferred to a verbal description.

In order to avoid certain anticipated problems, it is recommended to draw up and discuss together with students some methodological test questions, which help to bring attention to needed areas. Also, a list of common mistakes would be helpful for students, where each type of mistake is given a full description. In addition, different stages of essay writing could be, of course, practised with students by giving them smaller writing tasks. It also pays off to read and figuratively assess fellow students' essays in order to understand genre traditions and notice common mistakes. A written reflection task, i.e. an intermediary report to the tutor could also be incorporated into the essay writing process, which should give students an opportunity to reflect their experiences of writing while still in the process of writing their essays. Since writing is a social act requiring dialogue with an estranging thought and a relation to the expected reader, it may well be worthwhile attempting to prepare essay writing in pairs.

To sum up, it should be said that the necessary didactic changes in the course work, as well as tutor's more hands-on approach to guiding students, did indeed help to improve the academic essay writing skills of the students of Estonian literature and hopefully contributed to the overall prestige of the essay genre in higher education settings.

Keywords: action research, academic writing, teaching academic essay writing for undergraduates, tutor's feedback 